\title{
Medicinal plants used by inhabitants of the Shigar Valley, Baltistan region of Karakorum range-Pakistan
}

\author{
Zaheer Abbas', Shujaul Mulk Khan ${ }^{2 *}$, Jan Alam, Sher Wali Khan ${ }^{3}$ and Arshad Mehmood Abbasi ${ }^{4^{*}}$
}

\begin{abstract}
Background: The inhabitants of mountainous terrains depend on folk therapies to treat various ailments; however lack of plant based research and geographical constraints set the traditional knowledge in jeopardy. Present study is the first documentation on traditional uses of plant species by the inhabitants of the Shigar Valley, Karakorum Range, Northern Pakistan.
\end{abstract}

Method: Ethnobotanical data were collected over a period from July, 2013 to October, 2016 from 84 respondents, using semi structured questionnaire. Quantitative indices such as relative frequency citation (RFCs) and fidelity level $(F L)$ were intended to evaluate the importance of medicinal plant species.

Results: In total 84 plant species belonging to 36 families and 72 genera were recorded. Fabaceae was dominant with 7 species, followed by Asteraceae, Lamiaceae and Rosacea ( 6 species each). Leaves, root, flowers, seeds and fruits were the frequently utilized plant parts, whereas among drug formulations, decoction (49\%) was ranked first. Majority of the plant species were used to treat abdominal, respiratory and dermal ailments (31, 12 and 12, respectively). RFCs value ranged 0.477 to 0.11 for Tanacetum falconeri and Allium carolinianum, respectively; while Hippophe rhamnoides and Thymus linearis depicted 100\% FL. Comparative assessment with previous reports revealed that traditional uses of $26 \%$ plant species counting Hedyserum falconeri, Aconitum violoceum var. weileri, Arnebia guttata, Biebersteinia odora, Clematis alpine var. sibirica, Corydalis adiantifolia and Saussurea simpsoniana were reported for the first time.

Conclusion: The endemic medicinal plant species and traditional knowledge of Balti community living in extremely high mountains area were explored for the first time. A comprehensive survey of this region could be significant to drive the existing knowledge in market circuit with sustainable collection, and to evaluate economic potential of the plant species. Additionally, social livelihood could be reinforced through establishing collection sites, transformation and drying centres for micro and macro marketing of medicinal plant species.

Keywords: Medicinal plants, Shigar Valley, Karakorum, Mountain, Baltistan

\section{Background}

Mountain landforms cover about one quarter of the land surface and host $12 \%$ world's population [37]. These landforms have great influence on climatic, biological, ethnic, cultural and linguistic diversity of any region. In Pakistan, substantial rural population is living in the mountain ranges of Karakorum, Himalaya and Hindu

\footnotetext{
* Correspondence: shuja60@gmail.com; arshad799@yahoo.com

${ }^{2}$ Department of Plant Sciences, Quaid-i-Azam University, Islamabad, Pakistan

${ }^{4}$ Department of Environmental Sciences, COMSATS, Abbottabad, Pakistan

Full list of author information is available at the end of the article
}

Kush. The Karakorum ranges frame deep incised valleys in the extreme north of Pakistan, and provide several services to dwellers such as timber, fuel wood, fodder, herbal medicines etc. Because, harsh climate, remoteness and difficult access hamper development in basic services particularly, education and health [55]. Therefore, mountain people are considered as the most poorest and deprived population. Furthermore, the inhabitants of high mountain areas are more susceptible to various diseases owing to unsympathetic mountains' environment with unexpected fluctuations in seasonal temperature, 
light intensity, ultraviolet (UV) radiation and poor domestic hygiene [3]. The health facilities provided by government and non-governmental organizations (NGOs) are next to nothing for the inhabitants living in these remote areas. Consequently, in such circumstances plant based traditional therapies are the primary health care source to mitigate various health disorders.

Baltistan is an archetypal mountainous region of the Northern Pakistan with average altitude of $3555 \mathrm{~m}$ above sea level. Historically, it has often been referred as "Western Tibet" or "Little Tibet" $[6,58]$. The territories of the Baltistan region lie sparsely at acclivities and in deep mountains of Karakorum and Himalaya with unique landscape, climate, flora and fauna. However, remoteness, difficult access and inadequate funding may be the major handicaps to conduct field survey in these areas. Only few workers [11, $12,21]$, have conducted ethnobotanical survey in some parts of Northern Pakistan. Therefore, very limited ethnobotanical literature is available in the region [20,31]. Shigar valley is located in the Karakorum Ranges, and is the home of various peaks (including K2), glaciers and hot springs, which have always been the most preferred tracking places for visitors across the country and abroad. Ethno-botany is a recently introduced and rapidly flourishing field in this region, and is gaining adequate attention by researchers. Although, various ethnobotanical surveys have be conducted in different parts of Pakistan. However, Northern parts of country are still poorly explored. Therefore, present survey aimed to provide, the first inventory on ethno-pharmacological application of medicinal plant species used by the inhabitants of Balti community of Shigar valley, Karakorum MountainsPakistan.

\section{Methods}

Study area

Shigar Valley is a part of the central Karakorum ranges situated in the north of Skardu town at right bank of the river Indus (Fig. 1). It lies at $25^{\circ} 25^{\prime} 32^{\prime \prime} \mathrm{N}$ latitude and $75^{\circ}$ $42^{\prime} 59^{\prime \prime} \mathrm{E}$ longitude and covers an area of 4373 sq. km with altitudinal amplitudes of 2, 260 to $8611 \mathrm{~m}$ above sea level [45]. It borders with China fenced by K2 (Godwin Austin)

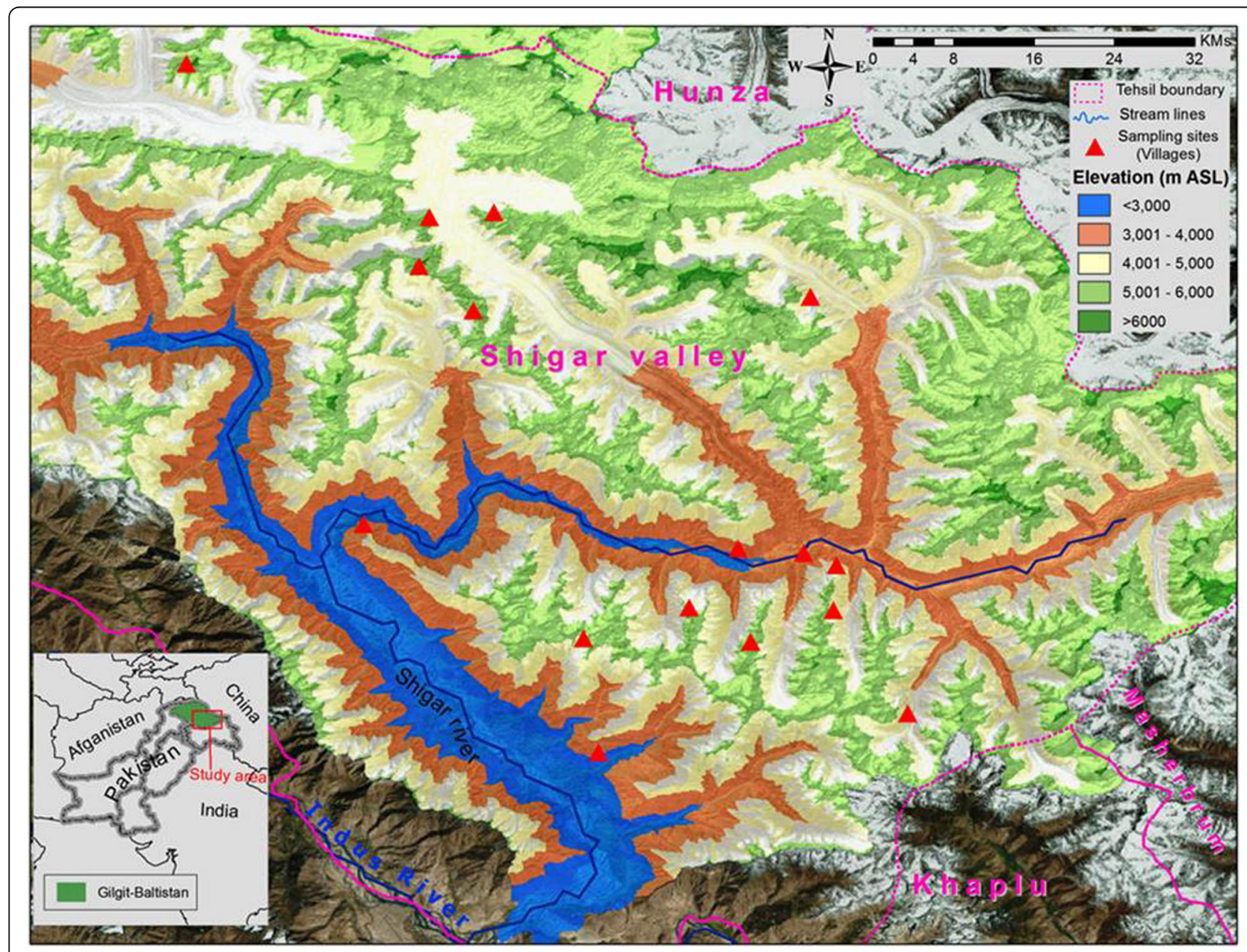

Fig. 1 Map of the study area showing survey sites 
between the territories [47]. The highest zone above $6000 \mathrm{~m}$ encompasses maximum ridges and peaks including K2 (8611 m), Broad Peak (8047 m), Angel Peak $(6858 \mathrm{~m})$ and Skil Brum $(7360 \mathrm{~m})$. Settlements are distributed in small villages on alluvial fans, terraces and gentle slopes at altitude of $2300 \mathrm{~m}$ (Marapi), $2790 \mathrm{~m}$ (Arando) and $3050 \mathrm{~m}$ (Askole). The valley experiences dry, hot and sunny summer with intensive radiation providing very short growing season for native flora [48].

Shigar Valley was ruled by Raja dynasty 'Amacha' and the period of Raja ruling system was known as Chou-Tus (Raja's period) in Balti dialect [6]. This autocratic system remained in power till the middle of nineteenth century (H. $[26,46])$. The presence of human community in Baltistan is prior to the birth of Guatama Budha (563 BC). The indigenous people of the valley have migrated from different regions i.e. Ladakh (Indian Kashmir), Tibet (China) and HunzaNagar via mountainous tracks [60]. These migrants have intermixed culture and arose as single Balti ethnic group due to dominant Ladakhi and Tibetan Balti speakers. They speak an archaic non-written Tibetan dialect called Balti [14]. Balti caste has a number of lineage sub-groups (Clan), which are also known as mi-schir (pronounce as mee-ser) in local dialects. They are very traditional and still tightly knotted with Balti culture in constructions, house scheming, livestock homes; dressing, agricultural activities, domestic and farming tools, games and rustic practices.

\section{Data collection}

Ethnobotanical survey was conducted from July, 2013 to October, 2016 in seventeen sites of the study area (Fig. 2). Field trips and interviews were planned in early spring i.e. March to June (off vegetation season), while keeping in mind the cold climate and short vegetation season of the area. Eighty four people were interviewed in Balti dialect without distinction of gender after seeking the consent, while semi structured questionnaire as explained previously $[16,41]$ was used to collect data. Interviews were taken in houses, people gathering place, mosques and Jamias (second time Islamic schools). After inquiring the demographic background of the respondents, information were collected on local name of plant species, part used, drug preparation, mode of administration and ailments treated. Afterwards a separate list of reported medicinal plant species with local name was developed by sorting questionnaires along with their ethno-medicinal uses.

\section{Sampling, preservation and identification}

The plant sampling was done in summer. Each specimen was tagged with its local name in the field (Fig. 2), prostrated in blotting papers and kept in filed plant presser. The perplexing plant species were confirmed by local respondents showing plant materials and/or their pictures. Dried specimens were poisoned using Mercuric chloride and absolute alcohol (2 g mercuric chloride $+1000 \mathrm{~mL}$ absolute alcohol), then mounted herbarium sheets [39]. Preserved specimens were identified by Taxonomists of Hazara University Herbarium, Mansehra Khyber-Pukhtunkhwa Pakistan, Karakorum International University Gilgit-Baltistan, Pakistan and with the help of available literature i.e. Flora of Pakistan $[8,43]$ and the flora of China. The botanical names and plant families were confirmed by angiosperm phylogeny group and The Plant List. The plant specimens were given the voucher numbers and kept in the Herbarium of Hazara University, Mansehra, Pakistan.

\section{Ethno-botanical data analysis}

Data were analysed using ethnobotanical indices i.e. relative frequency of citation (RFCs) and fidelity level (FL) in order to evaluate the importance of the recorded species.

\section{Relative frequency citation (RFCs)}

Reveals the importance of each species and is calculated on the basis of the frequency of citation 'FC' (the number of informants mentioning the use of species), using formula as described before [51]. The FC value is divided by total number of informants participating in the survey $(\mathrm{N})$, without considering the use-categories

$$
\mathrm{RFCs}=\frac{F C s}{N}
$$

Where, FCs is the number of informants who mentioned the use of a plant species and $\mathrm{N}$ is the total number of informants.

\section{Fidelity level (FL)}

Is the ratio between number of informants who mentioned the use of a plant species for a particular purpose and total number of informants who mentioned the use of that plant species for any purpose (regardless the category). FL indicates the percentage of informants claiming the use of plant species for same major purpose. The $\mathrm{Fl}$ of the species was calculated using the method as adopted by [7]. High FL values (100\%), are obtained for plant species, where almost all uses refer to same purpose. The low FLs are usually obtained for plants that are used for numerous purposes.

$$
\mathrm{FL}(\%)=\frac{l p}{l u} \times 100
$$

$I p$ is the number of informants who independently suggested the use of a plant species for a particular disease 


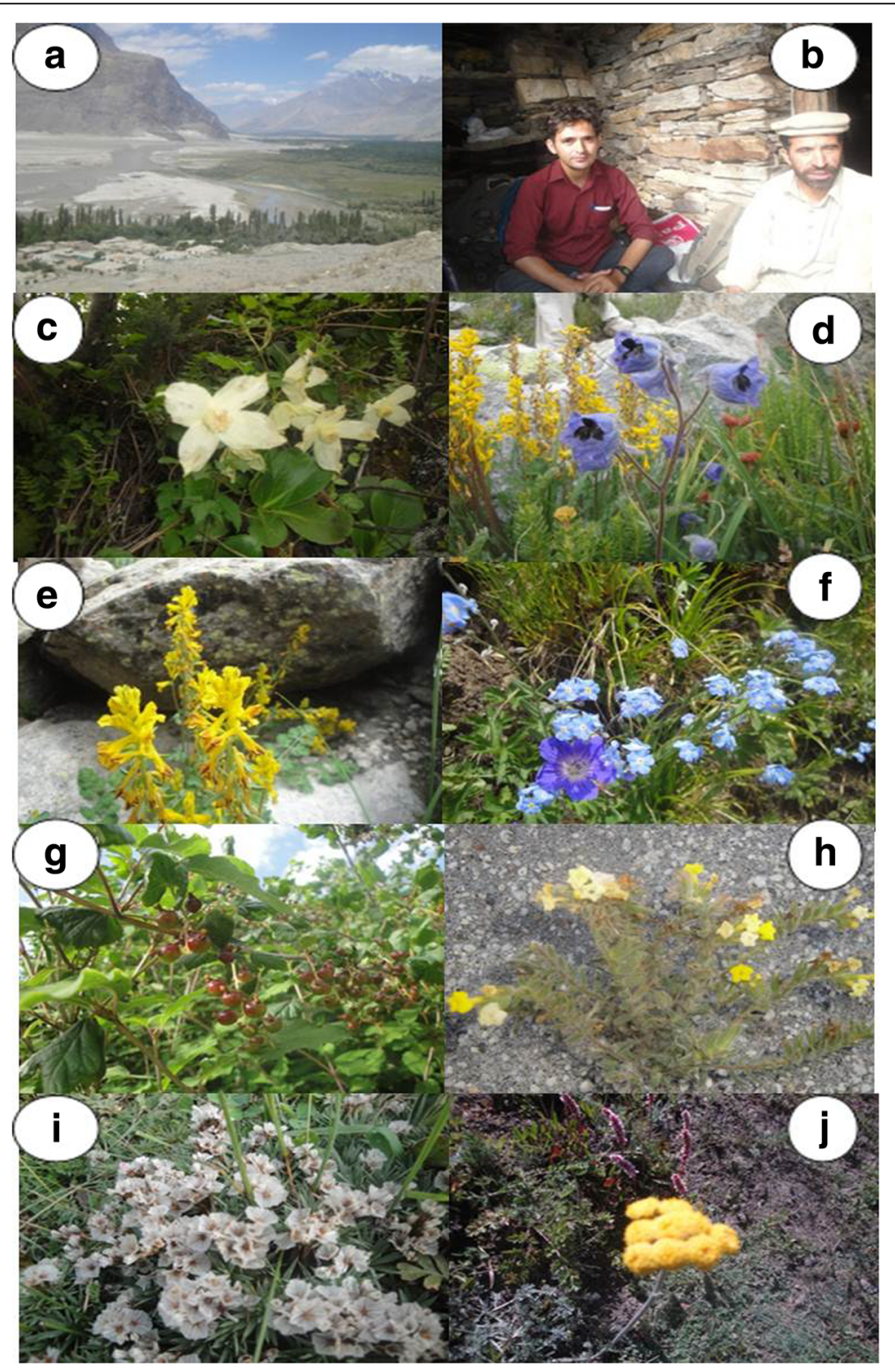

Fig. 2 a Landscape of the Shigar valley $\mathbf{b}$ Principal author with local guide in shepherd's house in alpine pasture c Clematis alpina var. sibirica a very rare medicinal plant of the study area $\mathbf{d}$ Delphinium brunonianum a high altitude medicinal species $\mathbf{e}$ Corydalis adiantifolia a newly reported medicinal plant from the region $\mathbf{f}$ Myosotis alpestris commonly distributed species from sub alpine to alpine zone $\mathbf{g}$ Ribes himalayense a medicinal shrub and local wild fruit $\mathbf{h}$ Arnebia guttataa lower altitude rare species $\mathbf{i}$ Acantholimon lycopodioides $\mathbf{j}$ Tanacetum falconeri common high altitude species

and $I u$ is the total number of informants who mentioned the same plant for any disease.

\section{Results and discussions}

\section{Demographic feature and indigenous knowledge}

In total 84 respondents including $73.80 \%$ male and $19.67 \%$ female were interviewed to collect data on medicinal uses of plant species from seventeen villages without gender distinction (Table 1). Due to Islamic instructions, communal restrictions and isolated society, usually female avoid to participate and hare knowledge, because of Islamic instructions, communal limits and isolated society. The informants were categorized in three age groups i.e. 2040 year, $40-60$ year and above the age 60 years. The middle age people (40-60 years old) had more indigenous knowledge compared to other age groups. This may be due to lack of interest in early age people about traditional remedies, and loss of mammary in elderly people because of age factor.

As far as education of the informants was concerned, majority of the respondents (75.40\%) were uneducated, 
Table 1 Demographic feature of respondents in the Shigar Valley

\begin{tabular}{llll}
\hline Variables & Categories & Number of persons & Percentage \\
\hline Sex Ratio & Women & 22 & 25.19 \\
Age Groups & Men & 62 & 73.80 \\
& Between 20 & 21 & 29.50 \\
& and 40 years & & \\
& Between 40 & 47 & 45.90 \\
& and 60 years & & \\
& Above 60 years & 16 & 24.59 \\
Education Level & Illiterate & 56 & 75.40 \\
& Primary & 9 & 4.920 \\
& Middle & 5 & 6.550 \\
& High School & 7 & 4.920 \\
& Graduate & 6 & 3.280 \\
& Masters & 1 & 4.920 \\
Social Livelihoods & Farmers & 56 & 62.29 \\
& Shepherds & 7 & 8.190 \\
& Wood cutters & 4 & 6.550 \\
& Gems (mining) & 9 & 13.11 \\
& Healers & 4 & 4.920 \\
& Job Holders & 4 & 4.920 \\
& Town area & 28 & 42.62 \\
& Elevated areas & 56 & 57.37 \\
\hline
\end{tabular}

however $24.60 \%$ were literate: having primary to masters level of education. Local inhabitants of the valley have different sources for survival. Most of them are farmers, shepherds, wood cutters, gemstone workers and job holders. It was interesting to know that local healers treat villagers and extend their traditional therapeutic knowledge among other people free of cost. The people of less developed and elevated zone possess adequate knowledge on medicinal use of native flora compared to those who live in towns. However, rapid modernization and effortless access to allopathic medicines might be the main causes that are diminishing the traditional knowledge of the dwellers.

\section{Ethno-floral diversity, availability and habit}

A total of 84 medicinal plant species belonging to 72 genera and 36 families were used by the inhabitants of the area to treat various health disorders. An enumeration of all recorded species including botanical name, local name, voucher specimen number, family, habit, availability, locality, parts used and drug description is provided in (Table 2). Fabaceae was the leading family with 7 species, followed by Asteraceae, Lamiaceae and Rosacea each was represented by 6 species. The therapeutic significant of the first four families may be associated with common distribution of species belong to these families in the study area. Asteraceae is one of the largest families in the flora of Pakistan, and its prevalent distribution throughout the country may be the reason behind being dominant. Likewise, same family been reported as a leading family in the previous studies conducted in surrounding areas of Shigar Valley [1, 12, 21]. However, Khan (2007) reported Rosaceae as the most prevailing family from various valleys of Himalaya and Karakorum ranges of mountains [29, 31]. These findings indicate the ample indigenous knowledge, varied selection and rich diversity of medicinal flora of the region.

Inhabitants of the Shigar Valley use cultivated and wild plant species (73.80 and $22.19 \%$, respectively) in traditional drug therapies, which is in agreement with previous study conducted in Haramosh and Bugrote valleys, in Gilgit-Pakistan [34]. Except for Equisetum arvense and Ephedra gerardiana rest of the species were angiosperms. Herbs were the dominant with $69 \%$ contribution (Fig. 3), followed by shrubs, trees and shrub lets (14, 13 and 4\%, respectively). The climatic conditions, wide distribution and easy access may be the reasons behind prevailed herbaceous habit in the area $[2,3,35]$.

\section{Part(s) used, drug preparation and administration}

The plant part(s) and their use number i.e. use more than one part of plant as drug source, depend upon the availability and indigenous knowledge of local community. The parts of plant species used were grouped in seventeen (17) categories on the basis of their types and number such as: as branches, bulb, flower, fruit, leaves, root, seed, seedling and whole plant were one part used categories (Fig. 4), whereas fruit \& floral buds (Prunus armeniaca), fruits \& leaves (Hippophe rhamnoides subsp. turkestanica), inflorescence, root latex and powder (Ferula jaeschkeana), leaves \& inflorescence (Salix alba), root bark \& fruit (Rosa webbiana), seed \& leaves (Pimpinella diversifolia) and, stem bark and seed (Fraxinus xanthoxyloides) were two parts used categories. Leaves were the most frequently used plant parts (16 species), followed by fruits (12), root (12) seed (11) and flowers (10).

The inhabitants of the study area use nine types of drug formulation as mentioned in Fig. 5, to treat various ailments. Among these, decoction was dominant (45 medications), followed plant part(s) eaten fresh (17 medications), cook/boiled/toasted (13 medications), powder and paste (5 medications each) and infusion (4medications). The modes of drug administration were divided in to three groups (Fig. 6). Around $83 \%$ recipes were taken orally, $11 \%$ were applied topically and $6 \%$ were used as oral and topical. 
Table 2 Family wise distribution of medicinal plants in study area

\begin{tabular}{|c|c|c|c|c|c|}
\hline Family & Number of Species & Percentage\% & Family & Number of Species & Percentage\% \\
\hline Alliaceae & 2 & 2.380 & Juglandaceae & 1 & 1.190 \\
\hline Apiaceae & 5 & 5.950 & Lamiaceae & 6 & 7.140 \\
\hline Asteraceae & 6 & 7.140 & Moraceae & 1 & 1.190 \\
\hline Berberidaceae & 3 & 3.570 & Oleaceae & 1 & 1.190 \\
\hline Betulaceae & 1 & 1.190 & Papaveraceae & 1 & 1.190 \\
\hline Biebersteiniaceae & 1 & 1.190 & Parnassiaceae & 1 & 1.190 \\
\hline Boraginaceae & 3 & 3.570 & Plantaginaceae & 1 & 1.190 \\
\hline Brassicaceae & 2 & 2.380 & Plumbaginaceae & 1 & 1.190 \\
\hline Capparidaceae & 1 & 1.190 & Poaceae & 3 & 3.570 \\
\hline Chenopodiaceae & 1 & 1.190 & Polygonaceae & 5 & 5.950 \\
\hline Cupressaceae & 1 & 1.190 & Punicaceae & 1 & 1.190 \\
\hline Cuscutaceae & 1 & 1.190 & Ranunculaceae & 6 & 7.140 \\
\hline Elaeagnaceae & 2 & 2.380 & Rosaceae & 6 & 7.140 \\
\hline Ephedraceae & 1 & 1.190 & Salicaceae & 2 & 2.380 \\
\hline Equisetaceae & 1 & 1.190 & Saxifragaceae & 1 & 1.190 \\
\hline Fabaceae & 7 & 8.330 & Solanaceae & 2 & 2.380 \\
\hline Fumariaceae & 1 & 1.190 & Urticaceae & 1 & 1.190 \\
\hline Gentianaceae & 1 & 1.190 & Zygophyllaceae & 1 & 1.190 \\
\hline Glossulariaceae & 3 & 3.570 & & & \\
\hline
\end{tabular}

\section{Classification of diseases and traditional therapies}

The life of rural peoples, particularly those who live in high mountain areas is very tough. The continuous effort of these people in order to survive in the social hierarchies makes them vulnerable to various types of ailments. The inhabitants of the Shigar Valley use medicinal plant species to treat 30 different ailments (Fig. 7). These ailments were grouped into fourteen categories by emec classification method viz. abdominal disorders treated by 31 species, dermal problems (12 species), respiratory disorders (12 species), miscellaneous

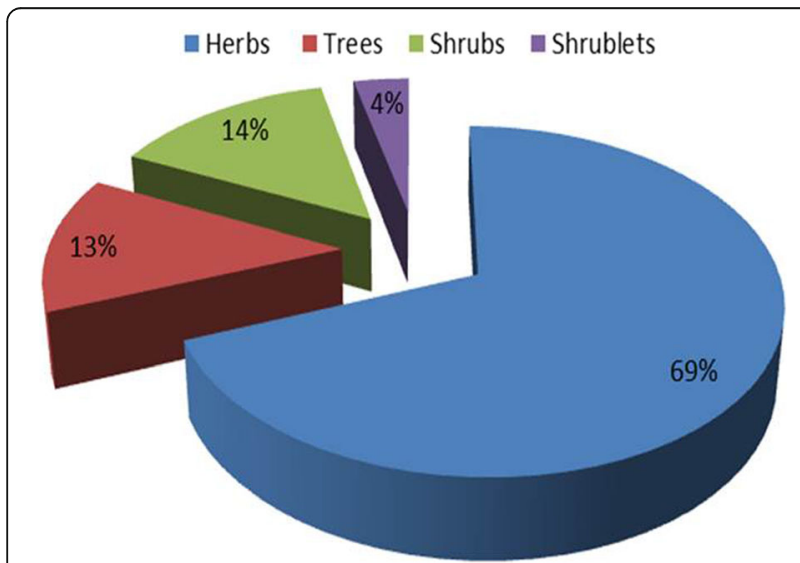

Fig. 3 Growth forms of used medicinal species including cold, cough, fever, migraine, vomiting (12 species), menstrual and pregnancy problem (6 species), cardiovascular disorders (6 species), tonics (5 species), urinary tract disorders (5 species), hepatic disorders (4 species), bones and joints issues (3 species), optical disorders ( 2 species), tooth problems (2 species), cancer (1 species) and diabetes (1 species). These observations were correlated with previous reports [18, 30, 56]. Gastrointestinal (GIT) disorders (i.e. constipation, indigestion, gastric trouble, dysentery, acidity, and stomach ulcer), skin diseases (pimples, pustules, and ringworm), respiratory tract infections (bronchitis, asthma, pneumonia) and bones/joint ailments (back ache, arthritis) were the common health problems. The gastrointestinal (GI) disorders may attributed to domestic hygienic conditions and dietary routine. Additionally, frequent use of teas, red pepper and less fibrous food could be a reason of GI infections. Likewise, intensive ultraviolet radiations and poorly managed public sanitation may be accountable for the prevalence of dermal problems. Moreover, prolonged harsh and hostile weather and allergens make dwellers vulnerable to get respiratory infections. The bones and joints ailments could be associated with the difficult topography and laborious life style (Fig. 8). Our findings provide an enthusiastic understanding on prevalence and distribution of the public sicknesses. In this context, present work offers imperative idea to frame long term health policies in 


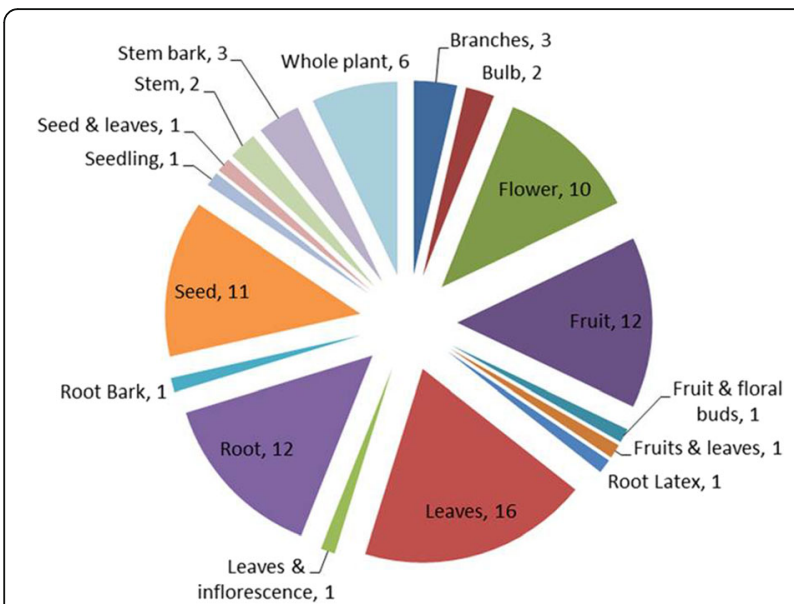

Fig. 4 Plant parts used in various disease treatments

order to convey health risk, precautions and effective treatment by integrated disease management.

Folk therapies used by the inhabitants of Balti communities were compared with previous work done in Gilgit-Baltistan, other parts of the country and Himalayan communities of India, Nepal and China [40]. The inhabitants of Shigar Valley use Betula utilis to treat ringworm, however same species is used against leprosy and earache in Chapursan valley, Hunza [57]. Delphinium brunonianum is effective for asthma, gastric trouble and trace release after delivery, but Hussain et al. [21] reported that in central Karakoram National Park this species is used to treat baldness, stomach ache and diarrhoea. Solanum nigrum has therapeutic importance of being liver tonic, to alleviate indigestion and eye pain, and to treat skin infections in India and the lesser Himalayas of Pakistan [4], but the inhabitants of Shigar Valley use this species only to treat tooth ache.

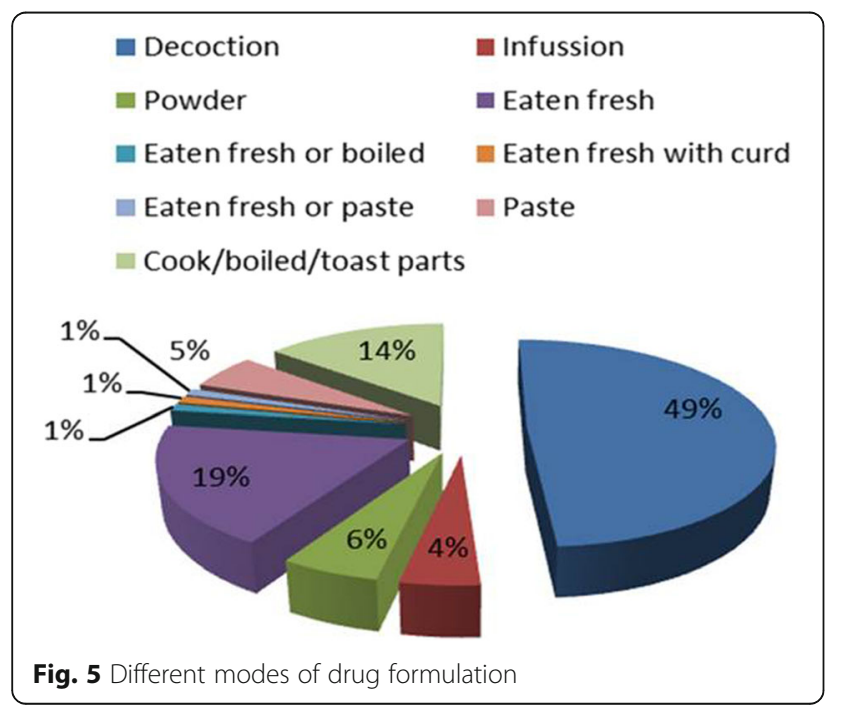

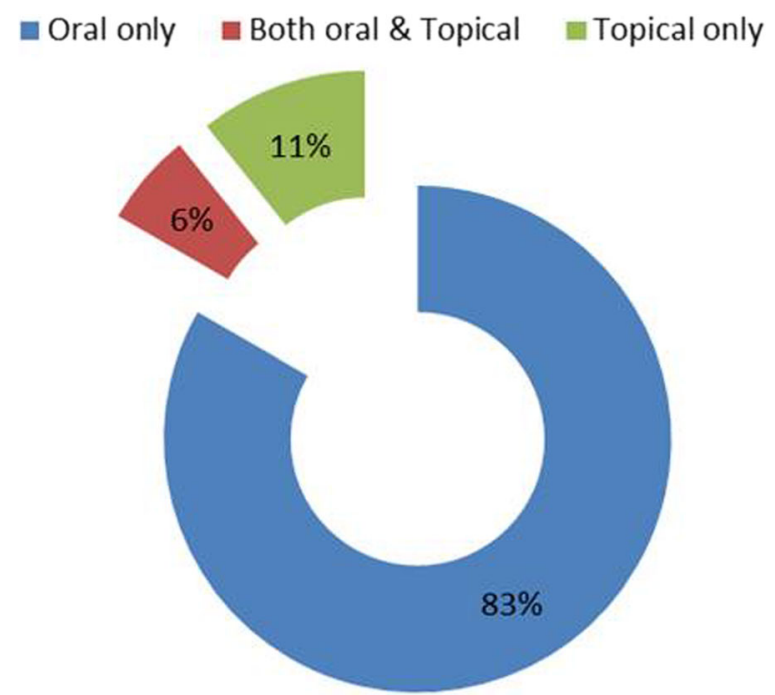

Fig. 6 Mode of administration

The inhabitants Swat Valley use Artemisia scopria to treat abdominal worms [19]. Same species has been reported as purgative in Gujrat Pakistan [22] and an effective remedy against hyper-acidic stomach in Zhejiang province, China [15]. However, in Shigar Valley the infusion of $A$. scopria are used to treat diabetes. In Shigar Valley, bulb of Allium carolinianum is used to treat gastrointestinal disorders and joint problem, but in Khunjerab National Park, Hunza, this species is used in flu and fever treatment [25]. Thymus linearis is used to alleviate abdominal pain and vomiting, while in Astore same species is used to kill abdominal worms [49].

Fruits and leaves of Hippophe rhamnoides subs. Turkestanica are used in the treatment of gastrointestinal disorders and skin diseases. Same species has been reported to treat cardiac diseases, cancer and stomach ache in Haramosh and Gilgit valleys-Gilgit [33]. Likewise, in Ladakh district of India, this plant is used to treat gynaecological disorders such as irregular menstrual cycles, amenorrhea or dysmenorrhoea [10], and to improve digestion [9]. Pimpinella diversifolia is among the most common medicinal herbs in the study area, which is used for abdominal disorders, fever and blood purification. In Lesser Himalayan region of Pakistan and Lao PDR, this species is used to alleviate gas problems and indigestion $[5,17]$. Thalictrum foliosum is used to cure diarrhoea and loss of appetite in Nepal [24], whereas the inhabitants of Shigar Valley use T. foliosum to treat eye ache. Present uses of Ephedra gerardiana and Foeniculum valgare to treat respiratory and gastro-intestinal disorders, respectively were comparable to previous reports from Rasuwa District, Central Nepal [54] and China [59]. Rumex nepalensis is used against stomach pain and itching in Garhwal Himalaya 


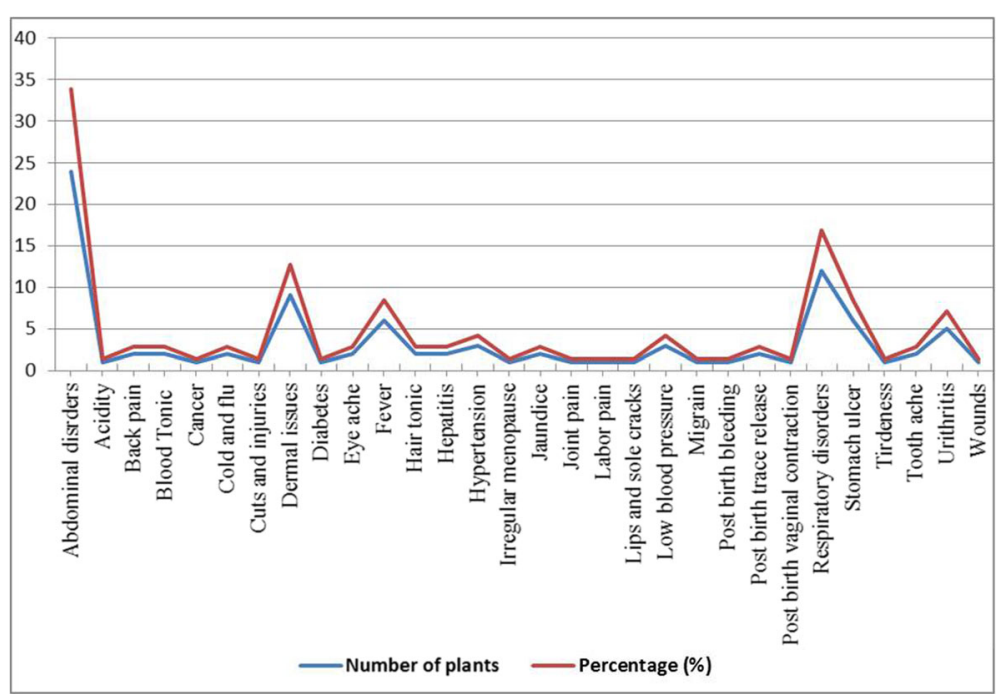

Fig. 7 Ailments categories and number of plant used

[53], but the inhabitants of the study area use this plant species to treat delivery pain.

The comparative assessment of present applications of medicinal plant species with reported literature revealed strong heterogeneity in folk uses. These findings evidently showed that most of the species are confined in the mountains of Karakorum, which have rarely been reported before. In the regional contrast, our study showed substantial harmony with the work conducted by Hussain et al. in the central Karakorum Range (I. [21]) and to some extent with the ethnobotanical survey carried out in Deosai plateau (Western Himalaya) Baltistan region [11, 12]. Although, both studies were focused on Balti communities, however present evaluation gives strong clues of the variations in ethnobotanical uses with respect to geographical location and difference in vegetation type $[27,28]$.

Our findings also depicted some resemblance with studies conducted in the Karakorum range of Haramosh

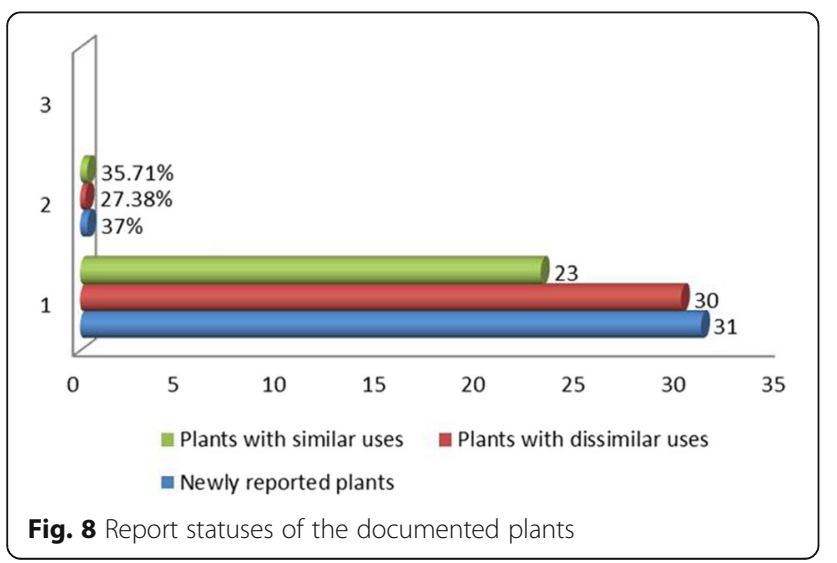

and Bugrote valleys by ([34]; and [32]). However, no understandable resemblance was observed with the ethnobotanical surveys conducted in other regional communities (Brushiski, Shina and Wakhi) except the work [25] in Khunjerab Hunza, where less than fifteen species were similar to present report. This may be because of floristic resemblance of these two mountainous areas; however different communities hold diverse ethno-flora and related traditional knowledge. Furthermore, change in indigenous knowledge might be linked with difference in area, language and the culture of local communities. Therefore, present assessment pointed out that, phytotherapies of Balti community are diverse and unique in these mountain terrains.

The findings of present study were also compared with previous studies conducted in the Himalayas of India, China and Nepal, which revealed that only few plant species were comparable which include: Allium carolinianum, Allium cepa, Artemisia scoparia, Berginia stracheyi, Hippophe rhamnoides and Thymus linearis to India, China and Nepal. These results may be linked with the floristic and cultural similarity, because analogous to Baltistan; Ladakh is also the home of Balti and Brokpa communities [13, 61], which have similar traditional knowledge on surrounding plant biodiversity. Additionally, due to similar climatic, topographic and edaphic conditions; the flora of study area shares a number of species with Ladakh, Jammu and Kashmir state of India [36].

\section{Quantitative assessment of ethnobotanical data}

Homogeneity in the traditional knowledge of medicinal plants used by the Balti community was evaluated using quantitative indices such as frequency of citation (RFCs) 


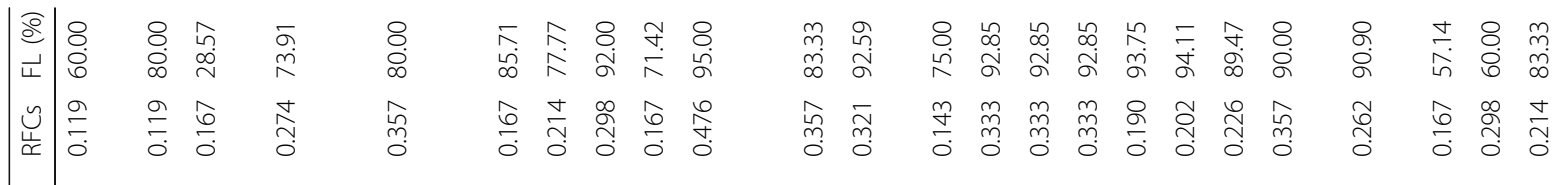

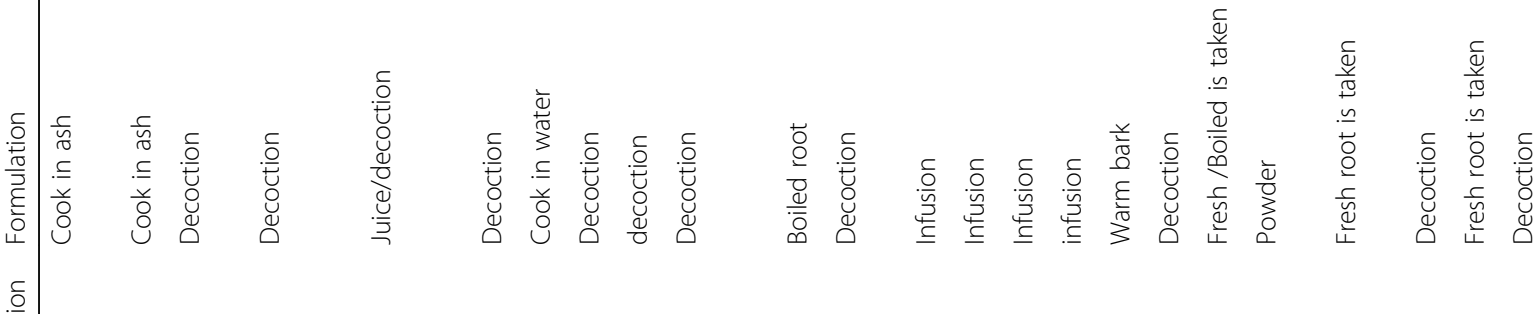

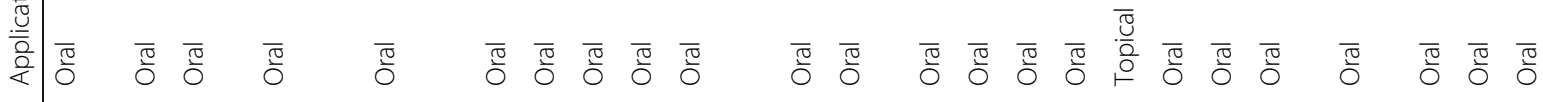

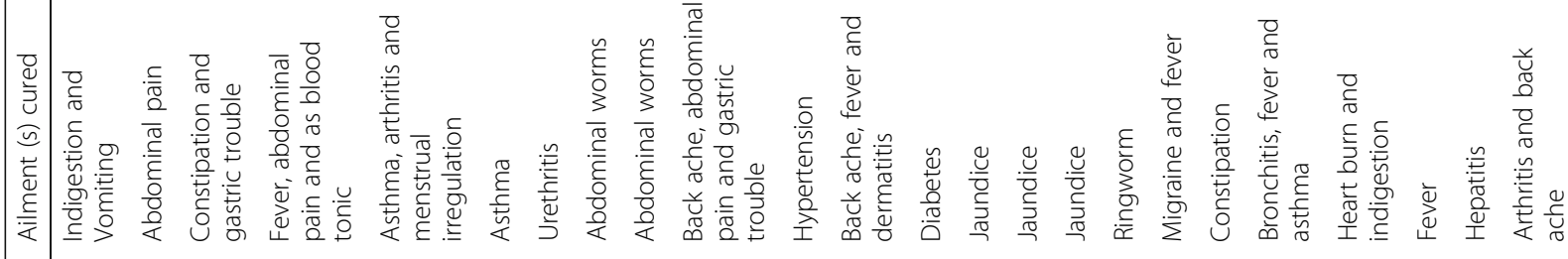

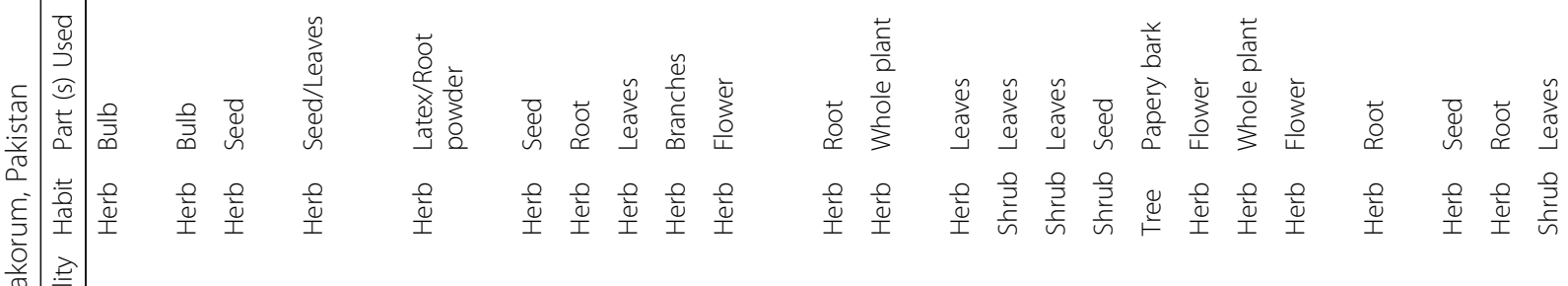

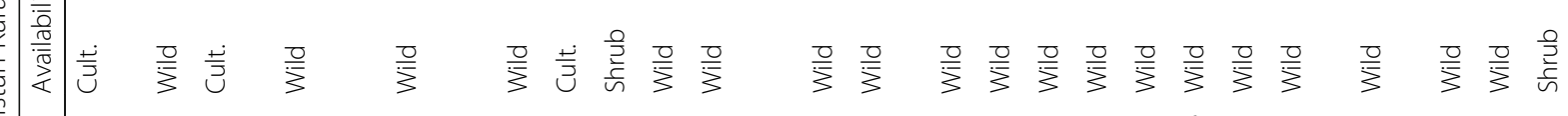

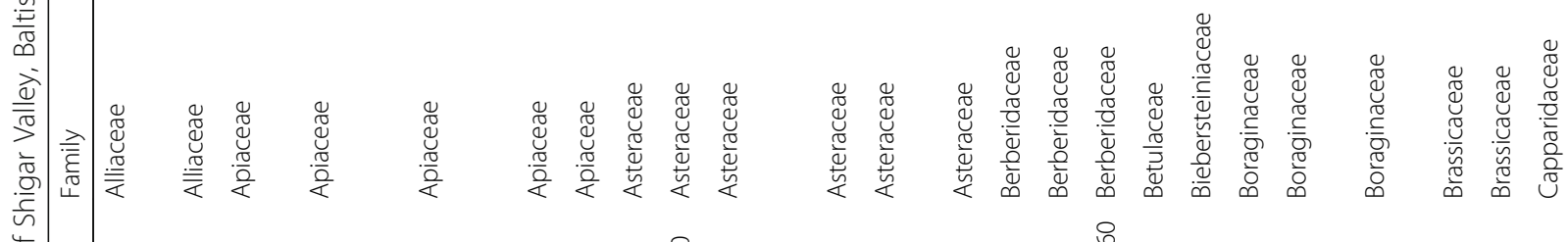

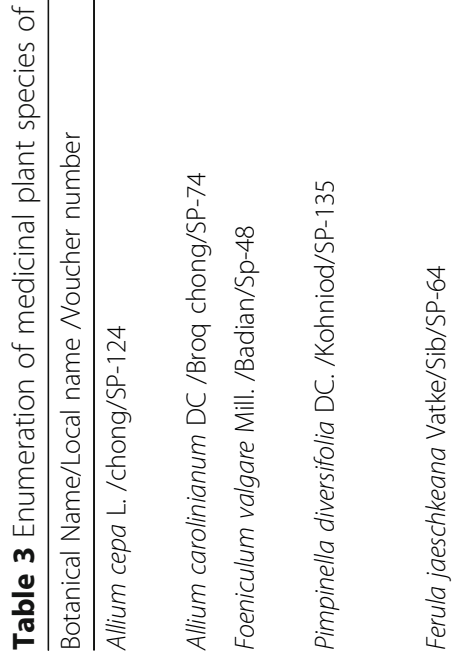

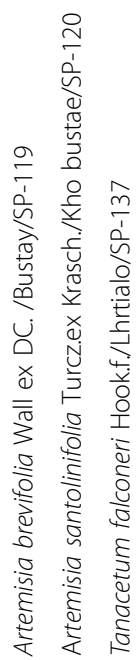

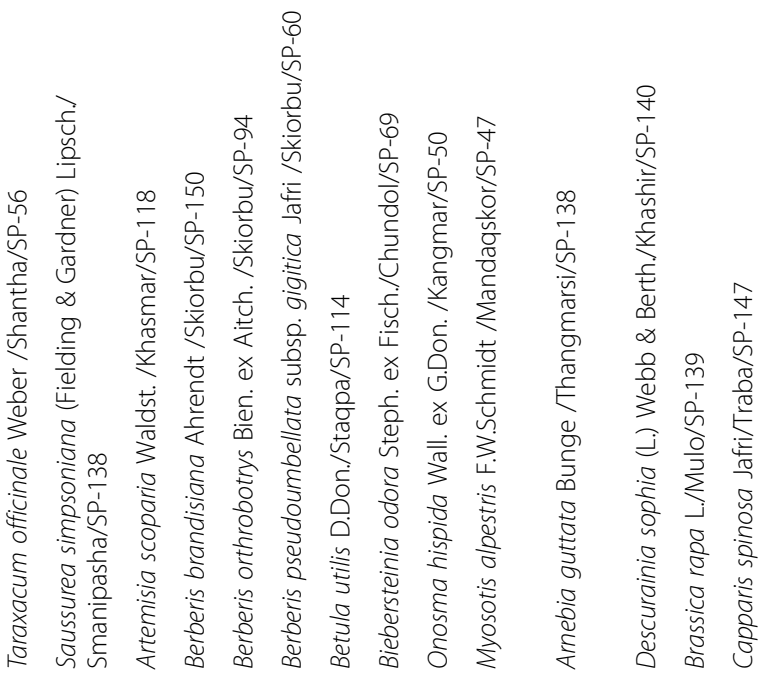




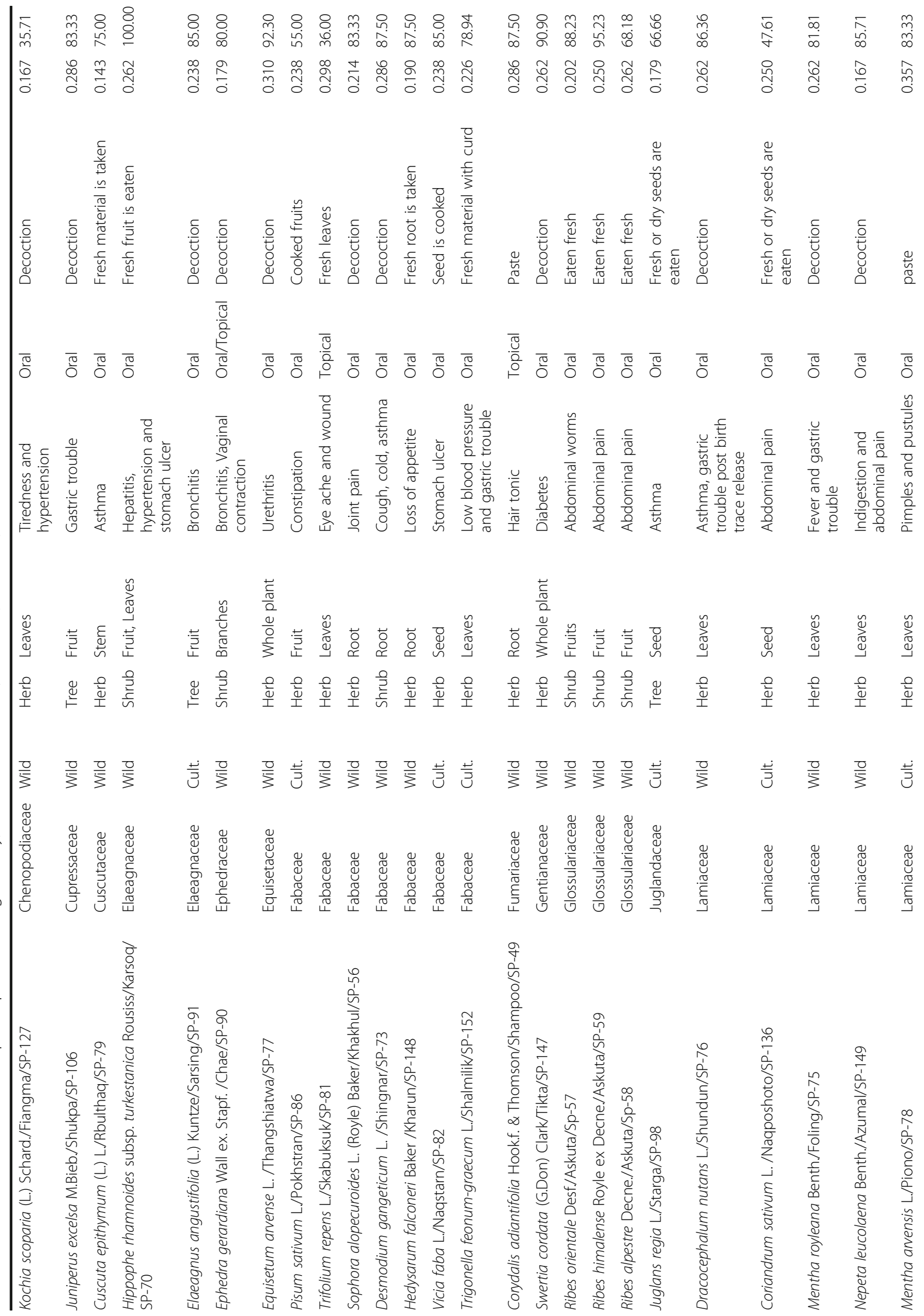




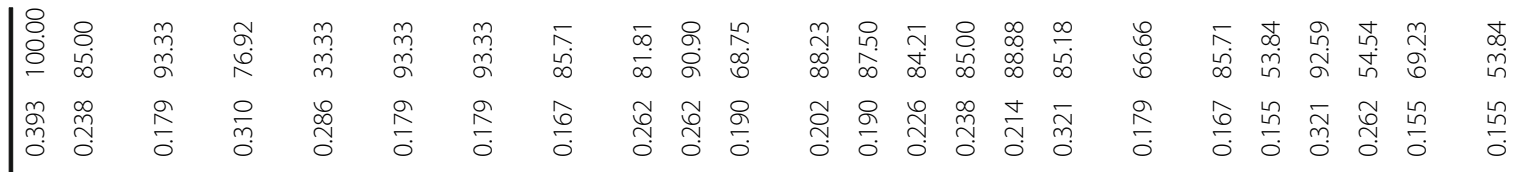

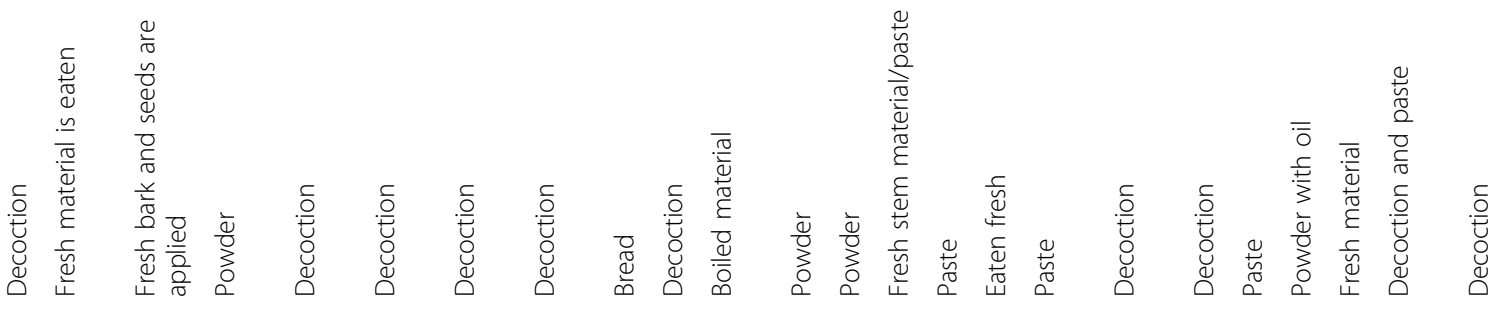

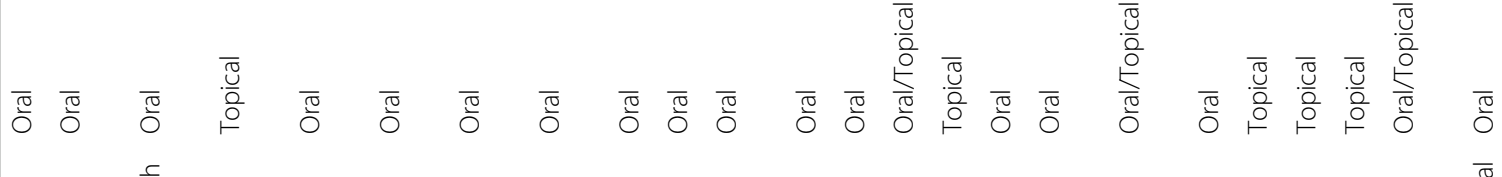

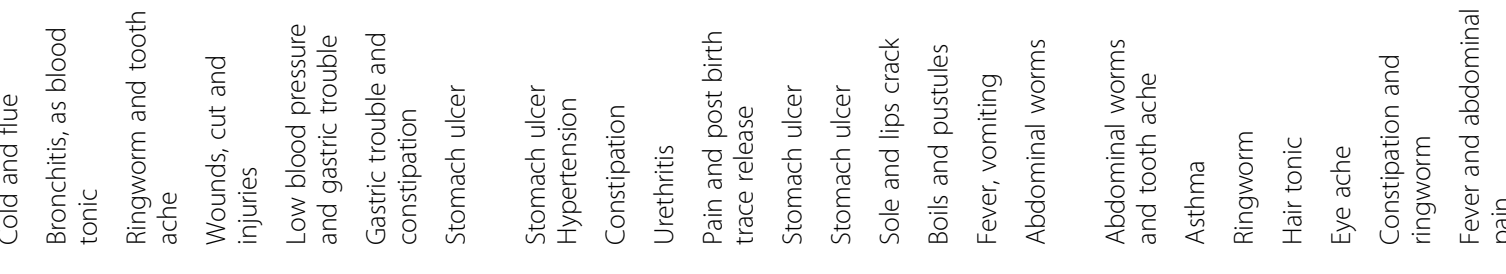




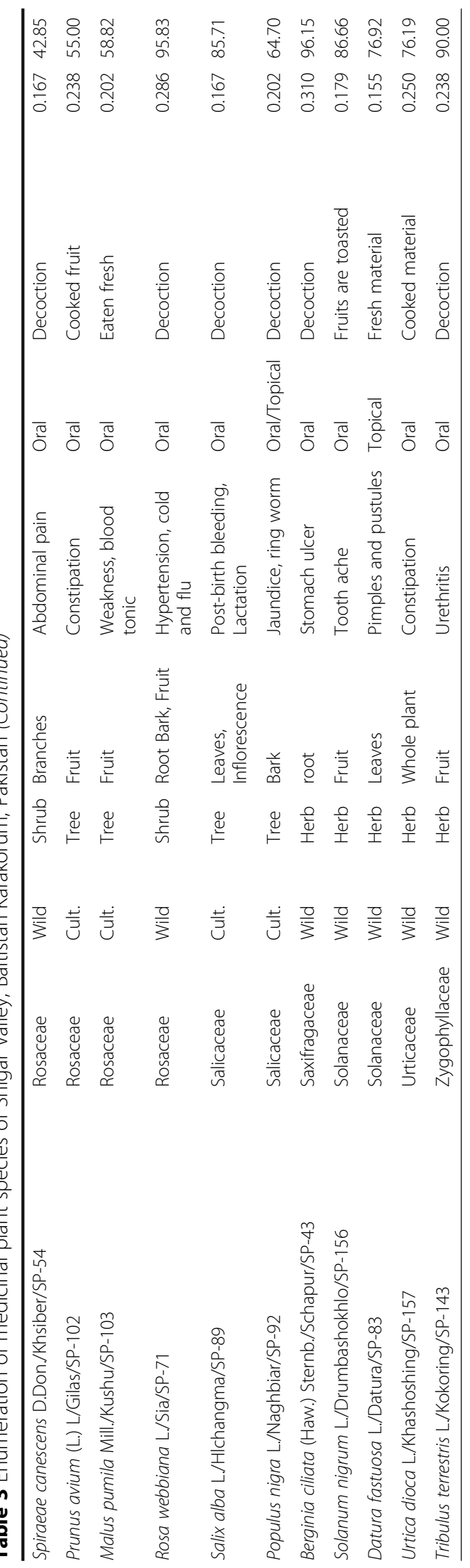


and fidelity level (FL). Relative frequency of citation (RFCs) of the reported species was ranged between 0.049 to 0.377. Tanacetum falconeri and Thymus linearis exhibited high RFSc value (0.377), followed by Taraxacum officinale (0.344) and Mentha arvensis (0.327), whereas lowest RFCs value (0.049) was calculated for Ranunculus repens. These findings were in agreement to Mutheeswaran et al. [42] in case of Allium cepa, whereas disagree in the case of Tribulus terristris.

Fidelity level (FL) indicates the most preferred species mentioned by local people to treat a particular disease. According to Lozada et al. information about FL of a species is of significant value compared to other plant based information [38]. The fidelity level of reported species ranged from 28.50 to $100 \%$. Two species i.e. Hippophe rhamnoides and Thymus linearis depicted 100\% fidelity level, whereas lowest FL was calculated for Foeniculum valgare $(28.50 \%)$. These findings were in agreement to [23]. Additionally, Ribes himalaynse, Rosa webbiana, Tanacetum falconeri, Beibersteinia odora and Betula utilis were the most preferred species with FL more than $90 \%$. The high FL of these species may be attributed to availability, distribution and detail information regarding therapeutic uses, dosage and recipes of these species.

\section{Novelty and future impact}

Present survey is the first comprehensive report on ethnomedicinal uses of plant species in Shigar valley, and reveals that the inhabitants of study area possess ample traditional knowledge on local flora. A careful probe on documented plant species for their medicinal and traditional uses from different areas of Pakistan revealed that, 22 plant species were reported for the first time from the study area, including five species: Aconitum heterophyllum, Salix alba, Prunus avium, Ranunculus repens, Populus nigra and Malus pumila, which were new to regional flora. Two endemic species i.e. Aconitum violoceum subs. Weileri and Arnebia guttata were used to treat women sterility, abdominal worm, tonsillitis, inflammation and indigestion by the inhabitants of the study area (Table 3). Among others: Artemisia santolinifolia was used against abdominal worms, Biebersteinia odora to treat migraine and fever, Corydalis adiantifolia as hair tonic, Clematis alpina var. sibirica and Desmodium gingeticum against cough, cold and asthma, Acantholimon lycopoidioides for stomach ulcer, Dracocephalum nutans to treat asthma, gastric trouble, and post birth trace release, Ferula jaeskeana for arthritis, asthma, menopause, Fraxinus xanthoxyloides to expel ringworm and tooth ache, Hedyserum falconeri in case of indigestion, loss of appetite and constipation, Myosotis alpestre to treat asthma, bronchitis, and fever, Parnassia nubicola for low blood pressure, gastric trouble, Saussurea simpsoniana to treat back ache, fever and dermatitis, Sophora alopecuroides against arthritis and Rumex patientia for boils and pustules.

Present study illustrated diverse medicinal flora in the territories of Gilgit-Baltistan mountains. The exclusive alliance of medicinal plants, mountain restricted distribution and high level disagreement in traditional uses corroborate the significance of this study. Being the first inventory on medicinal flora of Shigar valley, present study offers baseline data for researchers, particularly interested in high mountains phyto-diversity and related traditional knowledge. The sub-alpine species in environs are practicable for conservation and cultivation $[44,50,52]$. The abundance of medicinal plant species in the study area could enhance the economic status of local communities by marketing and sustainable utilization. Local inhabitants can make their home gardens or micro park system of medicinally important species on their own land. However, illiteracy and lack of developmental packages are the major handicaps in the operation of such implications.

\section{Conclusion}

The wealth of endemic and indigenous plant knowledge of the Balti community living in extremely isolated and high mountain Shigar valley, Karakorum ranges-Pakistan is reported for the first time. This study presented ethnoflora and traditional knowledge of the local inhabitants of the area. However, it would be in jeopardy; if further inclusive research is not conducted. Because mountain dwellers are oblivious of the values of bio-cultural diversity and the rate of transformation of plant knowledge decreasing with the passage of time due to infusing allopathic drugs and changing life style. Therefore, a comprehensive study in high mountain areas could be of significant value to conserve the medicinal plant wealth and related traditional knowledge. Moreover, extensive ethno-medicinal studies could discover the hidden knowledge and may provide unique plant species for chemical screening, consequently may leads to novel drugs discovery.

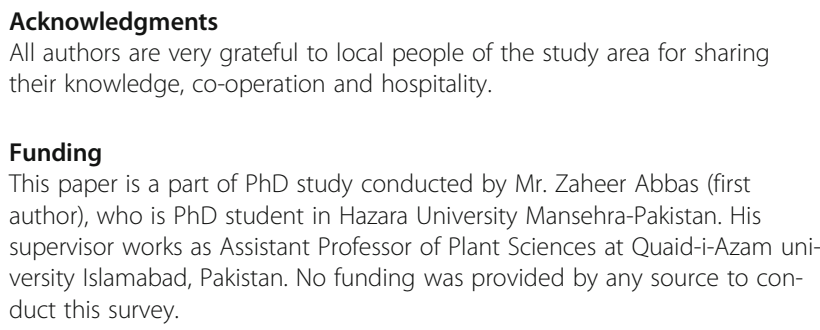

Availability of data and materials

We have already included all data in the manuscript collected during the field surveys.

\section{Declaration}

Medicinal plants used by the inhabitants of Shigar Valley, Baltistan region, Karakorum Range-Pakistan 


\section{Authors' contributions}

ZA conduct field survey and collect data, wrote first draft of the manuscript JA and SWK provided support in field survey, sampling and plant species identification, AP provided technical support and helped in write up and revision, SMK designed study and supervised the project, AMA help in data collection, analysis and write up. All authors read and approved the final manuscript.

\section{Ethics approval and consent to participate}

Present study is purely based on filed survey instead of human or animal trails. However, formal consent was received from informants regarding data collection and publication; then the Participatory rural appraisal (PRA) approach as mentioned in the Kyoto Protocol was applied with the consent of the informant. Ethical guidelines of the International Society of Ethnobiology (http://www.ethnobiology.net/) were strictly followed.

\section{Consent for publication}

Our manuscript does not contain any individual's person data; therefore we didn't take any consent for publication

\section{Competing interests}

The authors declare that they have no competing interests.

\section{Publisher's Note}

Springer Nature remains neutral with regard to jurisdictional claims in published maps and institutional affiliations.

\section{Author details}

${ }^{1}$ Department of Botany, Hazara University, Mansehra, Pakistan. ${ }^{2}$ Department of Plant Sciences, Quaid-i-Azam University, Islamabad, Pakistan. ${ }^{3}$ Department of Biological Sciences, Karakorum International University, Gilgit, Baltistan, Pakistan. ${ }^{4}$ Department of Environmental Sciences, COMSATS, Abbottabad, Pakistan.

Received: 22 April 2017 Accepted: 31 July 2017

Published online: 25 September 2017

\section{References}

1. Abbas Q, Qureshi R, Naqvi AUN, Khan SW, Hussain I. Floristic inventory and ethnobotanical study of the Naltar valley (Karakoram range), Gilgit, Pakistan. Pak J Bot. 2013:45:269-77.

2. Abbas, Z. (2012). "floristic diversity, cultural uses and phytosociology of Tormic valley Baltistan". M.phil Thesis, Quaid-i-Azam University Islamabad, Pkistan.

3. Abbas Z, Khan SM, Abbasi AM, Pieroni A, Ullah Z, labal M, et al. Ethnobotany of the Balti community, Tormik valley, Karakorum range, Baltistan, Pakistan. J Ethnobiol Ethnomed. 2016;12(1):38.

4. Abbasi AM, Khan MA, Ahmed M, Zafar M. Herbal medicines used to cure various ailments by the inhabitants of Abbottabad district, north west Frontier Province, Pakistan. Indian J Trad Know. 2010;9:175-83.

5. Abbasi AM, Khan MA, Shah MH, Shah MM, Pervez A, Ahmad M. Ethnobotanical appraisal and cultural values of medicinally important wild edible vegetables of lesser Himalayas-Pakistan. Ethnobiol Ethnomed. 2013:9:84.

6. Afridi, B. G. (1988). Baltistan in history: Emjay books international.

7. Alexiades, M. N., \& Sheldon, J. W. (1996). Selected guidelines for ethnobotanical research: a field manual: New York botanical garden

8. Ali, S., \& Nasir, E. (1970). Flora of Pakistan, 01-215. Department of Botany, University of Karachi, Pakistan, 2002

9. Ballabh B, Chaurasia O. Medicinal plants of cold desert Ladakh used in the treatment of stomach disorders. Indian J Tradit Knowl. 2009:8(2):185-90.

10. Ballabh B, Chaurasia O. Herbal formulations from cold desert plants used for gynecological disorders. Ethnobot Res Appl. 2011:9:59-66.

11. Bano A, Ahmad M, Hadda TB, Saboor A, Sultana S, Zafar M, et al. Quantitative ethnomedicinal study of plants used in the skardu valley at high altitude of Karakoram-Himalayan range, Pakistan. J Ethnobiol Ethnomed. 2014;10(1):43.

12. Bano A, Ahmad M, Zafar M, Sultana S, Rashid S, Khan MA. Ethnomedicinal knowledge of the most commonly used plants from Deosai plateau, western Himalayas, Gilgit Baltistan, Pakistan. J Ethnopharmacol. 2014;155(2):1046-52.

13. Bhasin V. Ecology and health: a study among tribals of Ladakh. Stud Tribes Tribals. 2005;3(1):1-13
14. Bielmeier, R. (1995). Balti Tibetan in its historical linguistic context. Karakorum-Hindukush-Himalaya: Dynamics of change, Part II, 583-610.

15. Chaudhary Ml, He Q, Cheng Y, Xiao P. Ethnobotany of medicinal plants from tian mu Shan biosphere reserve, Zhejiang-province, China. Asian J Plant Sci. 2006;5(4):646-53.

16. Cotton, C. M. (1996). Ethnobotany: principles and applications: John Wiley \& Sons

17. de Boer H, Lamxay V. Plants used during pregnancy, childbirth and postpartum healthcare in Lao PDR: a comparative study of the Brou, Saek and Kry ethnic groups. J Ethnobiol Ethnomed. 2009;5(1):1.

18. Giday K, Lenaerts L, Gebrehiwot K, Yirga G, Verbist B, Muys B. Ethnobotanical study of medicinal plants from degraded dry afromontane forest in northern Ethiopia: species, uses and conservation challenges. J Herb Med. 2016;6(2):96-104.

19. Hamayun M, Afzal S, Khan MA. Ethnopharmacology, indigenous collection and preservation techniques of some frequently used medicinal plants of Utror and Gabral, district swat, Pakistan. Afr J Tradit, Complement Altern Med. 2006;3(2):57-73.

20. Hocking GM. Pakistan medicinal plants I. Plant Foods for Hum Nutr (Formerly Qualitas Plantarum). 1958;5(1):145-53.

21. Hussain I, Bano A, Ullah F. Traditional drug therapies from various medicinal plants of central karakoram national park, Gilgit-Baltistan Pakistan. Pak J Bot. 2011:43:79-84.

22. Hussain K, Nisar MF, Majeed A, Nawaz K, Bhatti KH. Ethnomedicinal survey for important plants of Jalalpur Jattan, district Gujrat, Punjab, Pakistan. Ethnobotanical Leaflets. 2010;2010(7):11.

23. ljaz F, Iqbal Z, Rahman IU, Alam J, Khan SM, Shah GM, et al. Investigation of traditional medicinal floral knowledge of Sarban Hills, Abbottabad, KP, Pakistan. J Ethnopharmacol. 2016;179:208-33.

24. Jha P, Karmacharya S, Chettri M, Thapa C, Shrestha B. Medicinal plants in Nepal: ecological society. Nepal: Kathmandu; 2008

25. Khan B, Abdukadir A, Qureshi R, Mustafa G. Medicinal uses of plants by the inhabitants of Khunjerab National Park, Gilgit, Pakistan. Pak J Bot. 2011:43(5):2301-10.

26. Khan, H. (1987). History of Baltistan: Lok Virsa translation.

27. Khan, K, Shah, M, Ahmad, H, Khan, SM, Rahman, I. U., lqbal, Z, \& Aldubise, A. (2017). Exploration and local Utilization of Medicinal Vegetation Naturally Grown in the Deusai plateau of Gilgit, Pakistan. Saudi Journal of Biological Sciences. https://doi.org/10.1016/j.sjbs (online).

28. Khan, M, Khan, SM, Ilyas, M, Alqarawi, AA, Ahmad, Z, \& Abd Allah, EF. (2017) Plant species and communities assessment in interaction with edaphic and topographic factors; an ecological study of the mount Eelum District. Swat, Pakistan. Saudi journal of biological sciences, 24(4), 778-786.

29. Khan, SM., Ahmad, H, Ramzan, M, \& Jan, MM. (2007). Ethnomedicinal plant resources of Shawar Valley. Pakistan journal of biological sciences: PJBS, 10(10), 1743-1746

30. Khan SM, Page S, Ahmad H, Shaheen H, Ullah Z, Ahmad M, et al. Medicinal flora and ethnoecological knowledge in the Naran Valley, western Himalaya, Pakistan. J Ethnobiol Ethnomed. 2013:9(4)

31. Khan SW. Inventoring and monitoring the flora of Haramosh and Bugrote valleys Gilgit, Gilgit Batistan. Karachi Pakistan: PhD Thesis, University of Karachi; 2007

32. Khan SW, Khatoon S. Ethno botanical studies on useful trees and shrubs of Haramosh and Bugrote valleys in Gilgit Notheren areas of Pakistan. Pak Bot. 2007a;39(3):699-710.

33. Khan SW, Khatoon S. Ethnobotanical studies on useful trees and shrubs of Haramosh and Bugrote valleys, in Gilgit northern areas of Pakistan. Pak J Bot. 2007b;39(3):699-710

34. Khan SW, Khatoon S. Ethnobotanical studies on some useful herbs of Haramosh and Bugrote valleys in Gilgit, northern areas of Pakistan. Pak J Bot. 2008;40(1):43

35. Klimes L. Life-forms and clonality of vascular plants along an altitudinal gradient in E Ladakh (NW Himalayas). Basic and Appl Ecol. 2003;4(4):317-28.

36. Klimeš L, Dickoré B. A contribution to the vascular plant flora of lower Ladakh (Jammu \& Kashmir, India). Willdenowia. 2005:125-53.

37. Körner, C., \& Spehn, E. M. (2002). Mountain biodiversity: a global assessment: Parthenon publishing group London.

38. Lozada M, Ladio A, Weigandt M. Cultural transmission of ethnobotanica knowledge in a rural community of northwestern Patagonia, Argentina. Econ Bot. 2006:60(4):374-85

39. Maden K. Plant collection and herbarium techniques. Our Nature. 2004;2(1):53-7. 
40. Mall B, Gauchan DP, Chhetri RB. An ethnobotanical study of medicinal plants used by ethnic people in Parbat district of western Nepal. J of Ethnopharmacol. 2015;

41. Martin G. Ethnobotany. In: A methods manual. People and plants conservation series. UK: WWF: Earthscan Publications; 2004.

42. Mutheeswaran S, Pandikumar P, Chellappandian M, Ignacimuthu S. Documentation and quantitative analysis of the local knowledge on medicinal plants among traditional siddha healers in Virudhunagar district of Tamil Nadu, India. J Ethnopharmacol. 2011;137(1):523-33.

43. Nasir, E., Ali, S., \& Stewart, R. R. (1972). Flora of West Pakistan: an annotated catalogue of the vascular plants of West Pakistan and Kashmir: Fakhri.

44. Schippmann, U., Leaman, D. J., \& Cunningham, A. (2002). Impact of cultivation and gathering of medicinal plants on biodiversity: global trends and issues. Biodiversity and the ecosystem approach in agriculture, forestry and fisheries.

45. Schmidt M. Pastoral systems in Shigar/Baltistan: communal herding management and pasturage rights. High Mountain Pastoralism in Northern Pakistan. 2000;132:121.

46. Schuler S. Story of the creation of Shigar. Cent Asiatic J. 1978;22(1-2):102.

47. Seong YB, Bishop MP, Bush A, Clendon P, Copland L, Finkel RC, et al. Landforms and landscape evolution in the Skardu, Shigar and Braldu valleys, central Karakoram. Geomorphology. 2009:103(2):251-67.

48. Seong YB, Owen LA, Bishop MP, Bush A, Clendon P, Copland L, et al. Quaternary glacial history of the central Karakoram. Quat Sci Rev. 2007: 26(25):3384-405

49. Shinwari ZK, Gilani SS. Sustainable harvest of medicinal plants at Bulashbar Nullah, Astore (northern Pakistan). J Ethnopharmacol. 2003;84(2):289-98.

50. Shinwari ZK, Qaiser M. Efforts on conservation and sustainable use of medicinal plants of Pakistan. Pak J Bot. 2011;43(1):5-10.

51. Tardío J, Pardo-de-Santayana M. Cultural importance indices: a comparative analysis based on the useful wild plants of southern Cantabria (northern Spain) 1. Econ Bot. 2008;62(1):24-39.

52. Tardío J, Pardo-De-Santayana M, Morales R. Ethnobotanical review of wild edible plants in Spain. Bot J Linn Soc. 2006;152(1):27-71.

53. Uniyal, B., \& Shiva, V. (2005). Traditional knowledge on medicinal plants among rural women of the Garhwal Himalaya, Uttaranchal.

54. Uprety Y, Asselin H, Boon EK, Yadav S, Shrestha KK. Indigenous use and bioefficacy of medicinal plants in the Rasuwa District, Central Nepal. J Ethnobiol Ethnomed. 2010;6(1):3.

55. Veith, C., \& Shaw, J. (2011). Why invest in sustainable mountain development?

56. Waheed Murad AA, Adnan M, Tariq A, Khan KU, Waheed S, Ahmad A. Ethnobotanical assessment of plant resources of Banda Daud Shah, district Karak, Pakistan. J Ethnobiol Ethnomed. 2013;9:77.

57. Wazir, S. M., Dasti, A. A., \& Shah, J. (2004). Common medicinal plants of chapursan valley, Gojal II, Gilgit-Pakistan. J Res (Science) Bahauddin Zakariya University, Multan, Pakistan, 15, 41-43.

58. Webster GL, Nasir E. The vegetation and flora of the Hushe Valley (Karakoram range, Pakistan). Pakistan J Forestry. 1965;15(3)

59. Yang L, Ahmed S, Stepp JR, Mi K, Zhao Y, Ma J, et al. Comparative homegarden medical ethnobotany of Naxi healers and farmers in northwestern Yunnan, China. J Ethnobiol Ethnomed. 2014;10(1):6.

60. Zakir, C. M. (1991). Siachen glacier: the World's highest battlefield: Urdu (Baltistan, Pakistan: Baltistan Academy, Ali Abad Skardu, 1991).

61. Zeisler B. On the position of Ladakhi and Balti in the Tibetan language family. Ladakhi Histories: Local and Regional Perspectives. Leiden, Boston: Brill; 2005

\section{Submit your next manuscript to BioMed Central and we will help you at every step:}

- We accept pre-submission inquiries

- Our selector tool helps you to find the most relevant journal

- We provide round the clock customer support

- Convenient online submission

- Thorough peer review

- Inclusion in PubMed and all major indexing services

- Maximum visibility for your research

Submit your manuscript at www.biomedcentral.com/submit

) Biomed Central 